\title{
YALE KAMISAR: COLLABORATOR, COLLEAGUE, AND FRIEND
}

\author{
Jesse H. Choper*
}

Yale Kamisar was absent when I was first interviewed by a number of faculty members from the University of Minnesota Law School where he was then teaching. These sessions took place between Christmas and New Year's in 1959 (when I was a third-year student at Penn), at the annual meeting of the Association of American Law Schools, that year in St. Louis. Yale had planned to be there, I was told, but cancelled because he was behind schedule in completing an article. So while I didn't meet him on that occasion, I surely learned what would ring familiar many times during our long and fruitful association.

About three weeks later, I met the man in person in the Twin Cities when I came for a formal interview at the Law School. His reputation already preceded him although he was only in his third year of teaching, following two years as an associate at Covington \& Burling, and an interrupted law school schedule for a stint of combat duty in Korea where, as a twenty-two-year-old infantry lieutenant, he commanded the assault platoon in an attack on "T-Bone Hill" and received the Purple Heart. (Given Yale's drive and tenacity, I have long been puzzled as to why the North just didn't give up then.) As I recall it, we had not yet finished shaking hands when he began quizzing me (to put it mildly) on a Student Comment that I had published in the University of Pennsylvania Law Review on a recent Fourth Amendment decision of the Supreme Court, Draper v. United States. ${ }^{1}$ I was critical of the ruling, which had upheld an arrest based on hearsay that a near-unanimous Court found to have been corroborated and thus to have constituted probable cause; Yale defended the Court's ruling. This was the first and the last time, at least in respect to criminal procedure, that I (or probably anybody else) reached a more liberal conclusion than Yale did. (I've always suspected that he supported my appointment to the faculty for my position, even though he continued to disagree with it - I can't recall him ever telling me that he had changed his mind.)

* Earl Warren Professor of Public Law, University of California at Berkeley (Boalt Hall). B.S. 1959, Wilkes College; LL.B. 1960, University of Pennsylvania; D. Hu. Letters 1960, Wilkes College. - Ed.

1. 358 U.S. 307 (1959). 
After immediately accepting Minnesota's offer, I joined the faculty a year later, in the Fall of 1961, after completing a judicial clerkship. Yale and I quickly became friends, and during that first year Bill Lockhart and he invited me to join them on a new constitutional law casebook for which Lockhart, then a distinguished senior constitutional law scholar, had a contract with West Publishing. So began my professional collaboration with Yale that has now extended more than four decades and which we both hope, if we remain lucky, will continue some time beyond that. In addition to nine editions of our cluster of casebooks, we also coauthored an article on the "Right to Counsel in Minnesota" which we described as containing "Some Field Findings and Legal-Policy Observations."2 (This is the only article in which Yale has taken on a partner in his entire career. Readers are free to draw their own inferences from this fact, especially since this was one of his earliest pieces.) It was the product of an empirical study in which Yale and I traveled throughout the state during the summer of 1963 interviewing participants in the criminal justice system. Our other formal venture was the annual Constitutional Law Conference, sponsored by U.S. Law Week in Washington D.C. for twenty years in the 80 s and 90s. I cannot say that Yale and I never had a serious disagreement during all this time, but there have been very, very few, virtually all of which were on substantive issues rather than on any personal conflicts. That is quite a record, one that I certainly had no reason to expect.

I am pleased to participate in this tribute to my old and esteemed friend on the occasion of his first formal retirement. (I anticipate there will be others to follow in years to come. I know that Yale still teaches winters at the University of San Diego where he has become a tenured professor.) I will leave to the distinguished group of scholars and jurists who are my fellow contributors the recounting of Yale's rise to the pinnacle in the field of criminal procedure, and to his longtime onthe-job colleagues at Michigan the rehearsing of his exploits in the classroom and more generally within the Law School. Rather, I would like to direct my brief remarks to several broader qualities.

I doubt that many (any?) would describe Yale as an easygoing fellow. Quite the contrary. He is a passionate advocate for his views, and a fierce competitor in all that he undertakes, be it on the tennis court, in a debate, or concerning matters of faculty governance. Still, although he may sometimes be highly critical of his intellectual adversaries, I have always found him scrupulously fair to those opponents, both in his writings and his platform appearances. As a consequence, many who have strongly divergent views from his on the

2. Yale Kamisar \& Jesse H. Choper, The Right to Counsel in Minnesota: Some Field Findings and Legal-Policy Observations, 48 MINN. L. REV. 1 (1964). 
rights of the accused continued regularly to join Yale in public dialogues (I think of Fred Inbau from a long time ago, and Paul Cassell more recently, in this connection) and to be his close professional associates and personal friends (Jerry Israel and Joe Grano come quickly to mind).

Of all the legal scholars I have observed, I know of none with a greater fervor for, and love of, research and writing. Yale is a perfectionist in his work, and thankfully overcomes the difficulty of some with this penchant of being unable to "let go" at some point. $\mathrm{He}$ revels in exploring his subjects in extensive breadth and, particularly, depth. A relentless attention to detail is revealed in the variety of sources found in the notes to many of his efforts, disclosing a zest for consuming materials such as the briefs in cases he is discussing, congressional testimony and speeches on the subject, and archaic newspaper and magazine articles on relevant issues. And, of at least equal significance, as the documentation in all his work reveals, he is extraordinarily generous - more so than most - in crediting others for their contributions to his thinking.

No portrayal of Yale's academic achievements would be complete without some recognition of his "other" field of inquiry: assisted suicide and euthanasia, an area that aligned him on the opposite end of the spectrum from most (if not all) of his usual allies. While this may initially appear aberrational, in fact, it demonstrates not only an enviable consistency but also one of Yale's most laudable qualities: concern for society's less fortunate underdogs, those whose interests have few advocates. This noble commitment probably marks the essence of his professional career.

On a number of occasions in recent years, Yale has mentioned that he has been told that he has mellowed. While I am not in regular contact with him, I haven't noticed it. His presence continues to fill the space around him. A conversation with him - "conversation" is probably a misnomer; "equal time" has never been one of its features - maintains its intensity. Like Ol' Man River, he just keeps rolling along. And we are the better for it. 